\title{
高段差乗り越え可能なクローラロボット機構* (自動段差登り動作の実現)
}

\author{
神村明载*1

\section{A Crawler Robot Mechanism Enabling High-Step Climbing (Realization of Automatic Climbing Motion)}

\author{
Akiya KAMIMURA*2 \\ *2 National Institute of Advanced Industrial Science and Technology (AIST), \\ 1-2-1 Namiki, Tsukuba-shi, Ibaraki, 305-8564 Japan
}

\begin{abstract}
We introduce a unique shaped crawler robot aimed for high-step climbing that is considered the most necessary ability in urban search and rescue operations. The crawler robot is composed of two triangular-shaped crawler devices connected by a center shaft, a straight crawler device and a twolink mechanism connecting the shaft and the straight crawler. The robot is very compact and light weight compared to other rescue robots. It has eight D.O.F. in total, four of which are for crawlers and the others are for shifting the shape of the robot. We confirmed that the proposed robot can get over $36 \mathrm{~cm}^{\text {high-}}{ }^{-}$step one-and-a-half times as high as its original height. We also implemented a height-independent climbing motion algorithm based on statics and geometrical analysis while climbing process. Various hardware experiments showed a capability of the developed robot and feasibility of the proposed motion algorithm.
\end{abstract}

Key Words: Mechatronics, Robot, Rescue, Inspection, Crawler Robot, Triangular-Shped Crawler, High-Step Climbing, Automatic Climbing Motion Algorithm

\section{1. 緒言}

近年，国内外において災害救助用口ボットとして 様々なタイプの移動ロボットが開発されている．災害 救助用口ボットは，操作者が無線遠隔操縦することで 人の進入が困難な場所や危険な場所の情報を取得する ことができるため，床下，天井裏，プラント等の狭险 部での点検作業を行う目的でその利用が始まっている。 たとえば, 家屋の床下検查では, $40 \mathrm{~cm}$ 程度の高さの隙 間を移動し，転がっている配管や配線，部屋と部屋を つなぐ $15 \mathrm{~cm}$ 程の段差を乗り越える能力が必要とされ る.また，搭載力メラ映像を見ながらの遠隔操作や， シロアリ等による材の被害状況や基礎に入ったクラ ックの確認，ガス漏れや温度・湿度情報などの無線に よる遠隔取得機能が必要とされる。本論文では，上記 の機能を有する移動ロボット機構の提案と, 自動的に 段差を超えるためのアルゴリズムの提案，実験による 検証を目的とする。

これまでに開発されてきた移動口ボットは，その移

*原稿受付 2009 年 2 月 26 日.

*1 正員，(独) 産業技術総合研究所(可 305-8564 つくば市並木 1-2-1).

E-mail: kamimura.a@aist.go.jp
動形態によって，大きくクローラ方式と車輪方式に分 けられる.クローラ方式は，接地面積が大きいことで 悪路や坂道での走行や，多少の段差を越える場合に有 効であるが，平地において移動速度を上げにくいこと や，クローラベルトの形状によっては摩擦の大きな路 面での旋回動作が行いにくいなどの問題がある.一方， 車輪方式では，比較的平坦な路面において移動速度を 上げることができ，旋回もスム一ズに行えるメリット があるが，段差越え能力は低く，砂地や摩擦の小さな 路面においてスリップする問題がある。本論文で提案 する移動ロボット機構では，高い段差を越えることを 目的としており，路面や段差でのグリップを優先して， クローラ方式の移動形態を採用している.

災害救助用ロボットや各種点検用の移動ロボットで は，一般的に悪路での走行の他に瓦碩や段差等を乗り 越える能力が必要とされる，段差越えを行う移動口ボ ット機構には，単純にクローラの先端に傾斜老付ける ことで段差を越えられるように工夫したもの (1)，(2)， 本体内部に重量マスを設置しそれを移動させることで 段差を越えるもの ${ }^{(3)}$ ，米国 iRobot 社の PackBot に代 表されるようなフリッパアームを複数搭載し，フリッ パアームを段差に押しつけ車体を浮かすことで段差を 越えるもの ${ }^{(4)}$ （7)，人び型の利点を活かしてが首 
を持ち上げるようにして段差を乗り越えるもの ${ }^{(8),(9)}$ ， 車輪方式やクローラ力式でリンク機構のアームを搭載 しており，それを利用して車体を持ち上げることで段

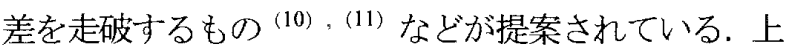
記の移動ロボット全てに共通して段差を越える際に重 要となるのが，口ボットの重心をいかに段差の上に移 動させるかということである. 重心送り機構の実現が, 段差越えにおいて最重要課題となる.

また，移動ロボットにおいて，上下逆さまになった り，穴にはまったりすることでデッドロック状態に陥 る場合が多々あり，これを避けるための機構も重要で ある. 通常，移動ロボットでは車体上面にカメラや各 種センサを搭載しており，上下逆さまになった場合の 対応がなされていないのが現状である，その他，搭載 するセンサの種類，数，操作方式，耐環境性能など議 論する要素は多いが，本論文では，高い段差を乗り越 えることができ，かつ現在の移動ロボットの問題点を 解決するべく開発を行った特殊なクローラタイプの口 ボット機構について説明する.以下， 2 章ではその開 発コンセプト，段差越えのための機構ついてまとめ, 3 章でロボットの構造やシステムの詳細について述べる. 4 章では自動段差登り手法の提案を行い，5章でロボ ットハードウェアによる様々な実験について紹介する. 6 章で, 結論と今後の課題について述べる.

\section{2. 段差越え權擭の提案}

$2 \cdot 1$ 開発のコンセプト 床下検査等狭盆部での 利用を目的とした移動ロボットの開発コンセプトにつ いて以下でまとめる。

1. 小型・軽量構造

险部での使用，小回りのきく移動機構，持ち運 びの容易性，バッテリの持続性を考慮して，小 型・軽量構造とする.

2.上下のない転倒に強い構造

ロボットが転倒した場合でも容易に復帰でき るよう上下のない構造とする.

3. 重心送り機構の実現

段差を越える際に必要となる重心送り機構を 複数リンクの屈伸により実垷する.このリンク機 構により，穴等にはまった際もデッドロックを回 避できるよう工夫する.

4. 多種多様な内界・外界センサを搭載 ロボット自体が小型軽量であるため, 主な使用 目的を情報収集として，ロボット位置の内界・外 界情報を計測するためのセンサを搭載する。

5． 無線遠隔操縦・情報収集伝達機能

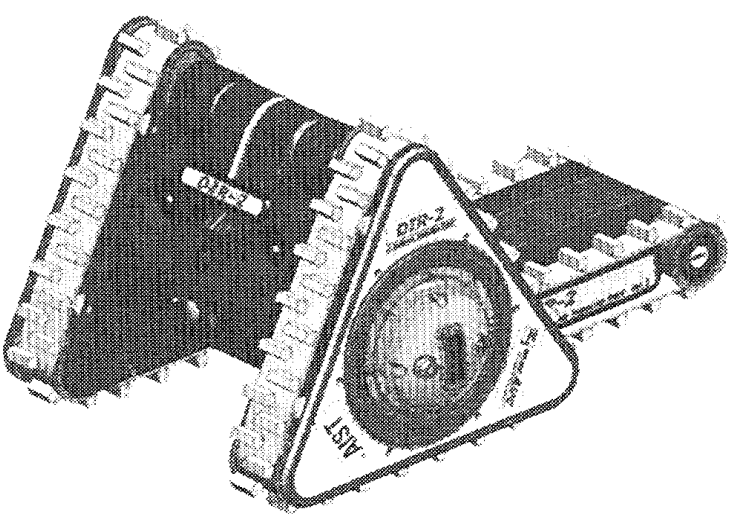

Fig. 1 Appearance of DIR-2 (Dexterous Inspection Robot).

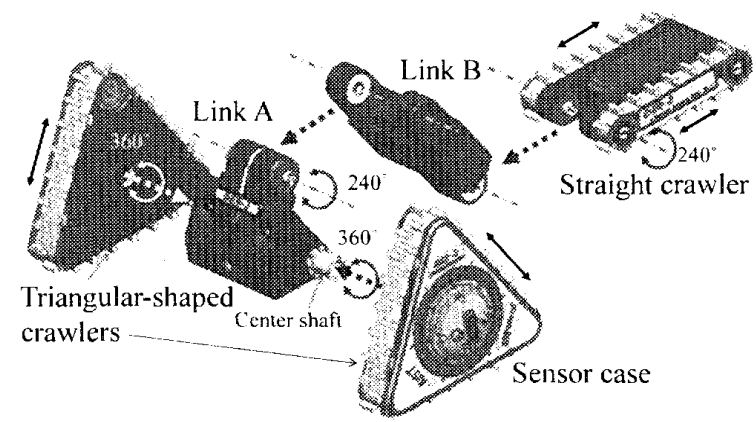

Fig. 2 Assembly diagram showing 5 components and 8 driving parts.

無線による遠隔操作を可能とし, ロボット位置 のカメラ映像やセンサ情報を遠隔で取得できる ものとする.また，将来的にロボット間で無線ネ ットワークを構成し，P 2 P で情報を無線伝達可 能なシステムとする.

6. グラフィカルで直感的な操作インターフェイス

現場に投入して，すぐに使用可能なシステムと し, なるべく直感的に操作が行え, ロボット位置 にお忛る情報や検知した異常をユーザに分かり やすく提示するための GUI を開発する.

次節では，以上の開発コンセプトに基づき開発を行 ったクローラタイプの移動ロボット機構について説明 する.

$2 \cdot 2$ 段差越え可能な機推の提案図 1 亿設計を 行った試作機の外観を示す。この試作機は，（株）A UC ${ }^{(12)}$ (群馬県安中市) と共同で開発を行った移動 検査ロボットの試作 2 号機で，Dexterous Inspection Robot の頭文字をとって, DIR-2 と呼んでいる. 図 2 に ロボットを構成する 5 つのユニットと 8 つの駆動部を 分かりやすく示した分解図を示寸。

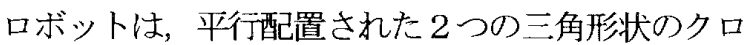
ーラユニット（以下三角クローラ），2つのリンクュ ニット（以下リンク $\mathrm{A}$, リンク $\mathrm{B}$ ），直線型のクロー 


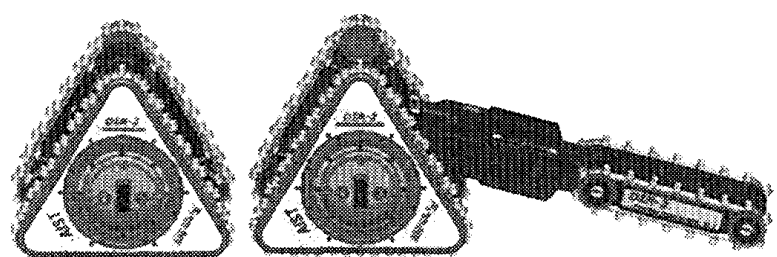

Fig. 3 Folding state (left) and Extended state (right) The link B and the straight crawler unit can be completely folded inside the triangular crawler unit in the side view.

ラユニット（以下直線クローラ）功構成される. 各 三角クローラの側面にはドーム状のセンサケースが配 置されている．2つの三角クローラの中心穴には，リ ンク A 下部側面に突き出した軸（以下中心軸）がベア リングを介して挿入され，内蔵したサーボモータによ り中心軸周りに $360^{\circ}$ 回転駆動できるよう設計されて

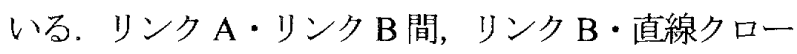
ラ間は、ジョイント結合されており，それぞれ結合回 転軸周りに $240^{\circ}$ の範囲で関節駆動可能となっている。 リンク B 内にはバッテリが格納されている. すべての 回転軸は中心軸と平行となる向きに設計してある.

ロボットの自由度としては，2つの三角クローラお よび直線クローラのクローラベルトの駆動用に 4 自由 度，2つの三角クローラの中心軸回りの $360^{\circ}$ 回転駆 動に 2 自由度,リンク $\mathrm{A}$ とリンク B 間の $240^{\circ}$ 関節駆 動に 1 自由度, リンク B と直線クローラ間の $240^{\circ}$ 関 節駆動に 1 自由度の計 8 自由度がある. 通常の走行は,

図1に示寸状態で, 左右クローラの駆動速度を調整す ることで前進，後退，旋回等を行う。

ロボットの構造は，三角クローラの中心軸周りに回 転対称であるため，特に上下前後の区別を設ける必要 はないが，カメラが設置してある方（図 1 左側）を前 方とし，また図 1 の状態を仮に上下とする。本構造で は，万一上下逆さまに転倒した場合でも，リンク $\mathrm{A}$, リンク $\mathrm{B}$, 直線クローラ部分は, 中心軸周りに 360 度 自由に回転できるため, 各自由度を駆動することで元 の状態に復帰可能である. またセンサケースがドーム 状であることで横転した場合でもデッドロックを回避 できる構造になっている.

リンク $\mathrm{B}$ ，直線クローラは，三角クローラ側面から みて, 図 3 左図に示すように完全に正三角形内部に収 納することができ，この状態でも走行可能である．こ のようにリンク B，直線クローラを収納することで， 狭险部での旋回を可能とし，さらにこの状態でコンパ クトに持ち運べる利点がある. (a)

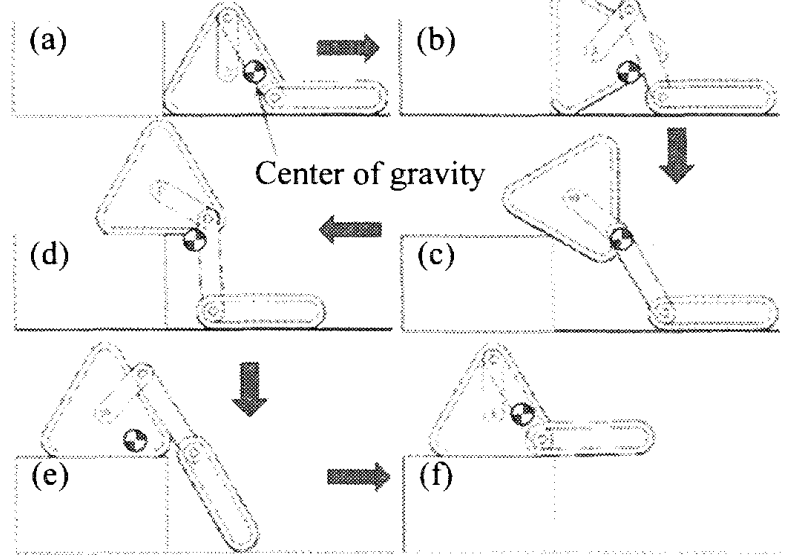

Fig. 4 A series of climbing motion sequences. Marks in the figure show center of gravity position.

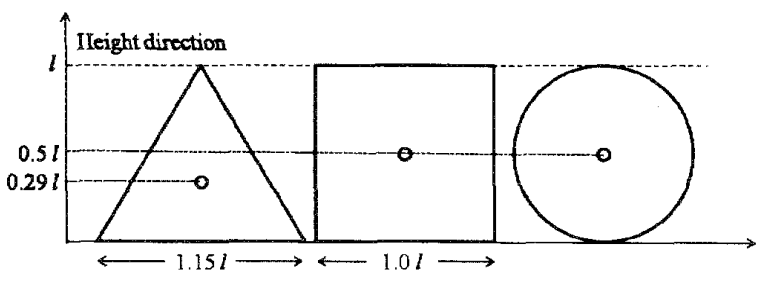

Fig. 5 Comparison of rotating crawler shape between triangular-shaped, square-shaped and circular-shaped.

本ロボット構造では，三角クローラ2つとリンク A のある前方部分の重量が最も重く(合計 $5.6 \mathrm{~kg}$ ) ，リ ンク B $(1.3 \mathrm{~kg})$ および直線クローラ $(1.7 \mathrm{~kg})$ 部は軽 く設計されている. リンクB と直線クローラは, 図 3 右図のように後方に三角クローラの一辺の 2 倍程度ま で伸ばすことができ，三角クローラの回転とリンク機 構により段差に登ることができる。

\section{$2 \cdot 3$ 段差登りの手順と三角クロ一ラ形状の評洒}

図 4 に, 提案ロボットによる段差登りの基本手順と 計算した重心の位置を示す。

（1）まず，三角クローラが段差側面に接触した状態か

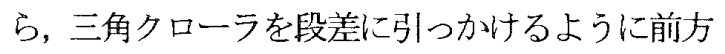
に回転させる (図 4(a), (b)) .その際, クローラ ベルトを前進方向に駆動しておくことで段差側 面および床面との閒のグリップを確保する.

（2）リンク A とリンク B 間, リンク B と直線クロー ラ間の角度を調整しながら, 三角クローラ部分を 段差面に載せる（図4(c)，(d)）。

(3) そのまま前進させ, 口ボットの重心が段差面に移 った状態で, リンク Aから後の関節を駆動して直 線クローラを段差面まで引き上げる (図 4(e), (f)) . 以上の動作を行うことで, ロボットの約 1.5 倍程度 の段差まで乗り越えることが可能である. 一方, 登る ことができる段差面の奥行きは, 図 $4(f)$ 状態で後転 しないための条件として, 重心の投影位置が段差面上 


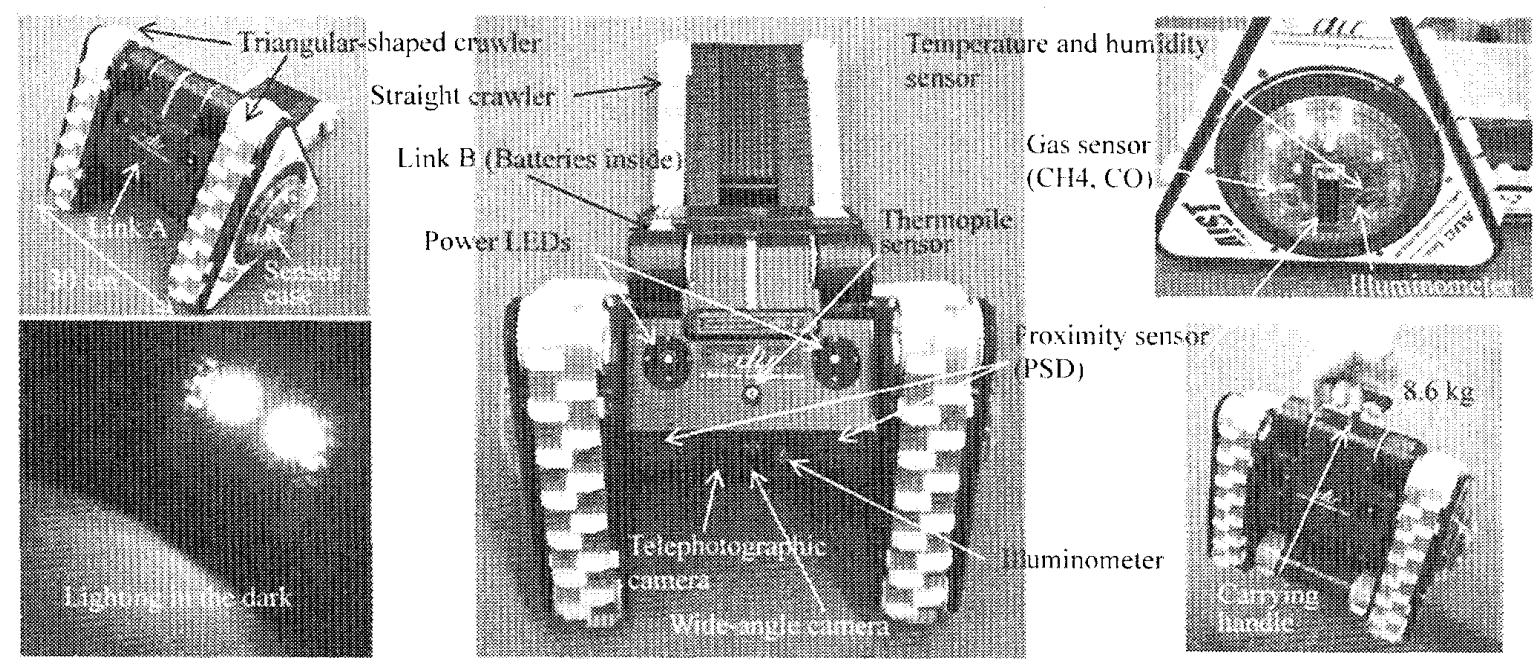

Fig. 6 Photos of DIR-2

にある必要性から，奥行きとして $18 \mathrm{~cm}$ 以上が必要で 女ると計算される。

図 5 は，軸回転対称な図形として，比較のため同じ 高さの三角クローラ, 正方形クローラ, 円形クローラ の回転軸位置（重心位置）を比較した図である，図か

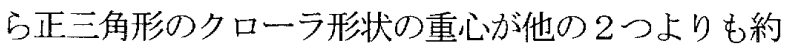
2 割も低し位置にあることが分かる. それにより，他 回転形状よりも同じ高さの段差に登る際に必要なリン ク長を短く設計でき, さらに低重心のため急傾斜の登 坂に有利であるなどのメリットがある，また，正方形 のクローラ形状よりも，一辺の長さが長いため, より 高さのある段差にもエッジを引っかけることができる. 以上の理由から三角形状のクローラを採用した。

\section{3. ロボットハードウェア}

\section{$3 \cdot 1$ 試作ロボットの開発 図6に, 開発した試} 作 2 号機, DIR-2 の外観と各部分の機能を示守. 表 1 にDIR-2のハードウェア仕様をまとめる.DIR-2では, 図7に示すロボット用サーボモータ 2 種類を新規に開 発した. 図7左は, クローラベルトを駆動するための 速度重視版で, 右はリンクの駆動や三角クローラの回 転をさせるためのハイトルク版である.制御基板には， 磁気式エンコーダ, モータドライバ, 電源回路, CPU, RS-485 通信チップが搭載されている。モータ搭載の CPU には, $360^{\circ}$ 位置速度制御, 回転速度制御, 動作 角度を制限するソフトリミット機能, 原点位置の自由 設定機能，回転量を測るためのパルスカウント機能， 各種センサフィードバック機能がプログラムされてお り,簡単なコマンドで駆動できるよう設計されている. 本サーボモータにより, 移動や段差越え時により細か な制御が行えるようになった。、ロボットの筐体は，防 塵・防滴構造になっており, 埃のある環境や小雨程度
Table 1 Specifications of DIR-2

\begin{tabular}{|c|c|}
\hline Item & Value \\
\hline Size & $\begin{array}{l}\text { Folding state: } 35 \mathrm{~cm}(\mathrm{~W}) \times 24 \mathrm{~cm}(\mathrm{H}) \times 27 \mathrm{~cm}(\mathrm{~L}) \\
\text { Extended state: } 35 \mathrm{~cm}(\mathrm{~W}) \times 24 \mathrm{~cm}(\mathrm{H}) \times 64 \mathrm{~cm}(\mathrm{~L}) \\
\text { One side of triangular crawler is } 27 \mathrm{~cm} \text { in length. }\end{array}$ \\
\hline Weight & $8.6 \mathrm{~kg}$ \\
\hline $\begin{array}{l}\text { Moving method } \\
\text { / Max. velocity }\end{array}$ & $\begin{array}{l}\text { Triangular shaped crawler and straight crawler } \\
/ \text { Max. } 2 \mathrm{~km} / \mathrm{h}\end{array}$ \\
\hline Gradeability & Max. 30 degrees (depends on friction of slope) \\
\hline $\begin{array}{l}\text { Turning circle } \\
\text { radius }\end{array}$ & $0 \mathrm{~cm}$ \\
\hline D.O.F & $\begin{array}{l}8 \text { (crawler (4), link mechanism (2), axial } \\
\text { rotation of triangular-shaped crawler device }(2))\end{array}$ \\
\hline Actuators & $\begin{array}{l}\text { Two types of A } 10 \text { developed servo motors ( } 2.4 \\
\text { Nm (18.5VDC) for crawlers and } 8.0 \mathrm{Nm} \\
\text { (18.5VDC) for others) }\end{array}$ \\
\hline CPUs & $\begin{array}{l}\text { Renesus SH7145 on main-controller board and } \\
\text { Atmel ATmegal68 on each servomotor, sensor } \\
\text { board and interface board }\end{array}$ \\
\hline $\begin{array}{l}\text { Internal } \\
\text { communication }\end{array}$ & RS485 multi-drop connection ( $115.2 \mathrm{kbps})$ \\
\hline $\begin{array}{l}\text { RF } \\
\text { communications }\end{array}$ & $\begin{array}{l}\text { Futaba } 2.4 \mathrm{GHz} \mathrm{RF} \text { modem and } \\
1.2 \mathrm{GHz} \text { wireless video transmitter } \\
\text { (Covered } 200 \mathrm{~m} \text { wide area in visible site) }\end{array}$ \\
\hline Battery & Two Li-Po batteries (18.5V 8.4 Ah in total) \\
\hline Operation time & 2 to 3 hours (depending on situation) \\
\hline Sensors / devices & $\begin{array}{l}\text { Wide-angle camera, Telephotographic camera, } \\
\text { Illuminometer, Infrared proximity sensor, } \\
\text { Thermopile sensor, 3-axis acceleration sensor, } \\
\text { Gyro sensor, Digital compass, Power LEDs, } \\
\text { Digital temperature and humidity sensor, GAS } \\
\text { sensor (CH4, CO) }\end{array}$ \\
\hline
\end{tabular}

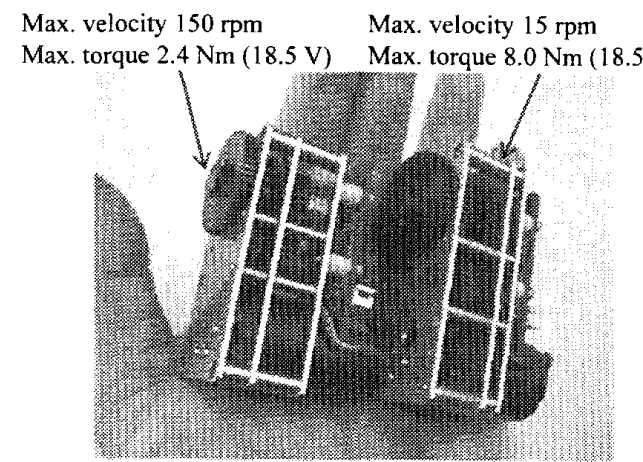

Fig. 7 Developed A10 servo motors. The left is for driving crawler belt and the right is for other parts requiring high torque. 


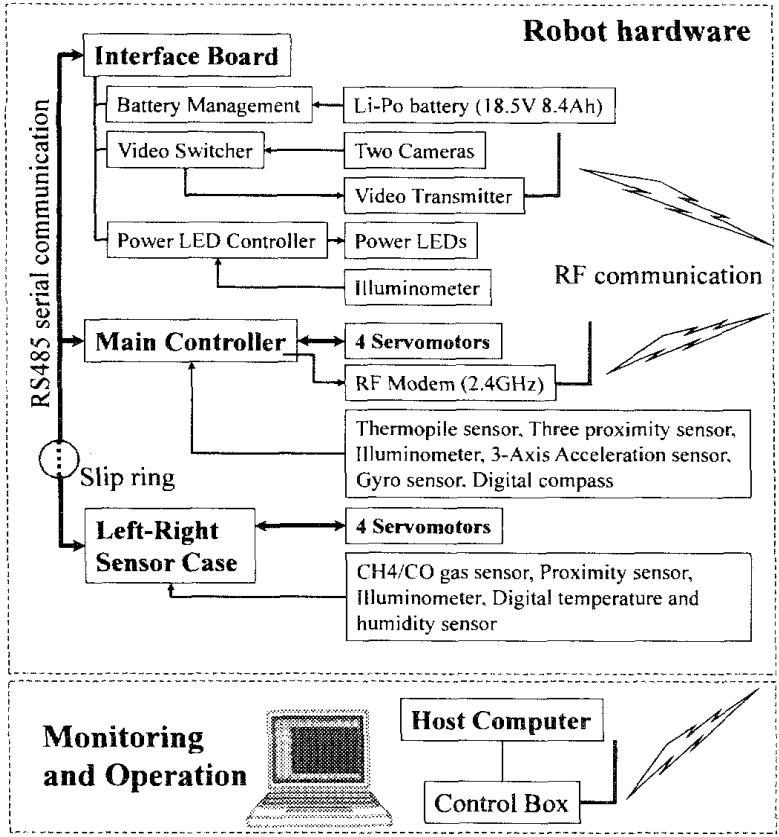

Fig. 8 Schematic of DIR-2 system configuration.

であれば使用可能となっている，また，収納式ハンド ルを備えており，持ち運びの容易性など実用性・利便 性も考慮している.

\section{3-2 ロボットのシステム權成 図 8 にDIR-2の} システム構成図を示す.ロボットハードウェア部には, メインコントローラ, 電源・カメラ・照明管理用イン ターフェイスボード，8つのサーボモー夕，左右セン サケースが含まれ，外部のホスト PC からコントロー ル BOX を介して無線によるコマンドの送受信やセン サ情報，カメラ映像の取得を行っている．ロボット内 は, 複数のCPU が図 8 太線に示すように一つのシリア ル通信バス（RS485）で結合され，各 CPU内に設定さ れた固有のコントロールテーブルに対してメインコン トローラから書き込み，読み込みを行うことで全体を 制御している. 外部のホスト PC からも無線により， 同様にメインコントローラ内のコントロールテーブル を読み書きすることができ，各種動作制御を行える仕 組みになっている，たとえば，取得したセンサ情報等 は, 各 CPU のコントロールテーブル上で随時更新され ており，ホスト PC からメインコントローラを介して 転送コマンドを送ることで情報を取得することができ る.

本ロボット機構では，2つの三角クローラはそれぞ れ軸周りに $360^{\circ}$ 回転するため, リンク $\mathrm{A}$ 側と三角ク ローラ間で電源ラインと通信ラインを通常の配線で結 ぶことができない，そこで，間にスリップリングと呼 ばれる回転体と固定機器間での通電を行ら装置を回転

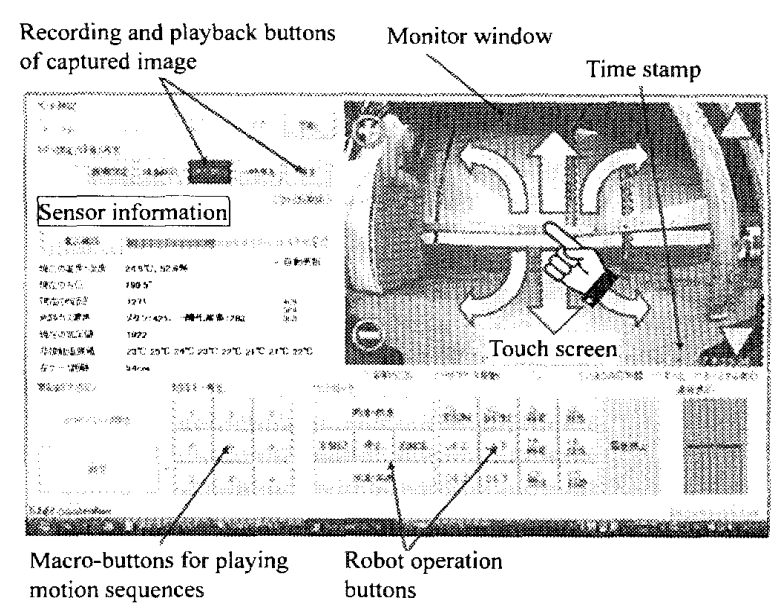

Fig. 9 Screen image of interface software on host PC

軸内に設置することで，三角クローラ側での十分な電 源容量と安定した通信速度を確保した。

$3 \cdot 3$ 操作インターフェイス 図9に, 操作イン ターフェイスのキャプチャ画面を示す．操作画面は, タッチパネル式になっており，画面に触れると，その 場所に応じたコマンドが無線でロボットに伝達される. 同時にロボット側の情報も無線で取得され，インター フェイス画面に反映される.

ロボットの移動操作は, 図9のモニター画面のロボ ットカメラ映像を見ながら，その画面を図 9 矢印に示 す上うに指でなぞることで前進・後退・旋回動作を行 う. リンク角度の変更等は, モニター画面下のボタン で操作できる，一連のボタン操作は, 図 9 左下のマク ロボタンを押すことで記録を開始し，ロボット側に時 系列のキーシークエンスデータとして保存される. 再 生する際もマクロボタンを押すことで記録動作を一発 で起動できる，この機能を使うことで，決められた段 差を乗り越えるシークエンスをあらかじめ作成してお くことで，操作者によらず段差越え動作が実現できる.

その他, カメラ映像のズームや，リアルタイム映像 の録画・再生等が可能である.

\section{4. 自堛段差登り動作の実現}

これまでブロックや階段のような段差登り動作は, 決められた高さを登るための動作キーシークエンスと して記録し，再生することで行っていた，しかし，異 なる高さの段差や，途中滑り等でタイミングがずれて しまった場合に対処できない問題があった.

本章では，段差登り時の静力学的・幾何学的な考察 を元に，段差の高さによらず自動的に登るためのアル ゴリズムを提案する．提案したアルゴリズムは，5章 のハードウェア実験において有效性の検証を行う。 


\section{4・1 段差登り時の静力学・幾何学 DIR-2 に上} る段差登りの動作手順は $2 \cdot 3$ 節およひ図 4 に示した通 りである. $2 \cdot 3$ 節におけりる(1)段差側面への接触，(3) 直線クローラの引き上げ動作は容易に実現できるので, ここでは(2)の三角クローラの段差面への持ち上げ動 作について考察を行う。

図 10 は，段差登り時の力とトルクを示している， $R_{1}, R_{2}$ は面からの抗力， $T_{1}, T_{2}, T_{3}$ はそれぞれモ 一タのトルク， $F_{2}$ は接触点におけるトルク $T_{1}$ によ る力, $F_{1}$ がクローラ推進力, 摩擦力その他のトル ク $T_{1}$ の接線方向の成分である. 図 10 左の状態で は, $R_{1}, R_{2}$ が面に対して進行方向側に傾いて掞り， 登る際に滑り落ちない状態を示している。この状 態を保持するようにクローラを駆動する.

三角クローラの前方回転方向に一定トルク $T_{1}$ を かけているのは，段差のエッジで $F_{2}>F_{1}$ になった 際に三角クローラが前方に回転し始めることを利 用して段差に登ったことを検知するためである。 三角クローラが回転を始める位置は，段差エッジ での $F_{2}$ と $F_{1}$ のバランスで決まり， $T_{1}$ が大きすぎ ると段差に登る前に前方へ回転してしまい，小さ すぎると段差のエッジを大きく越えても回転しな いことになる． $T_{1}$ の要件として, 図 10 左の状態で 最低三角クローラを段差側面に押しつけることが でき，かつ最大三角クローラ下部が面から離れて 回転しない範囲で値を選択する必要がある。

図 11 は，段差登り時の3つの姿勢・形における 計算した重心位置と転倒方向を示したものである. 段差が高くなるとリンクを伸ばす必要があり，直 線クローラの接地点と重心の投影位置が近づくた め不安定になりロボットが後転する場合がある.

図 11 左図の場合, 直線クローラの接地点よりも右 側に重心があるため右に倒れる（後転する）。図 11 中央の場合，ほぼ一致しているのでどちらへも 倒れる可能性がある. 図 11 右図では，必ず段差面 側に倒れる。よって，ロボットが段差面に対して 後転しないための条件として，まず図 11 左の状態 を避けるためにリンク B を鉛直になるように制御 し，リンク $\mathrm{B}$ を挟んでリンク $\mathrm{A}$ と直線クローラが 反対方向にあること，また図 11 の中央のようにり ンクが一直線になる状態をリンクの可動限界と設 定すれば良いことが分かる。

\section{$4 \cdot 2$ 自动段差登りアルゴリスムの提案 $4 \cdot 10$} 考察を元に，高さによらない自動段差登りアルゴリズ ムを提案する．使用するセンサ情報は，リンク Aの鉛 直軸からの姿勢角度（加速度センサ值より計算） $\alpha$ と

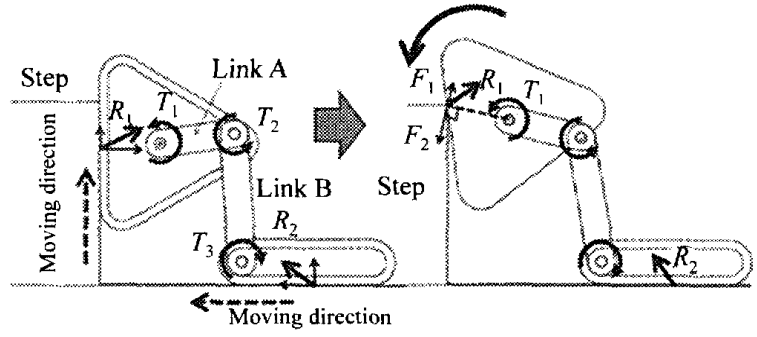

Fig. 10 Forces and Torques in climbing process.

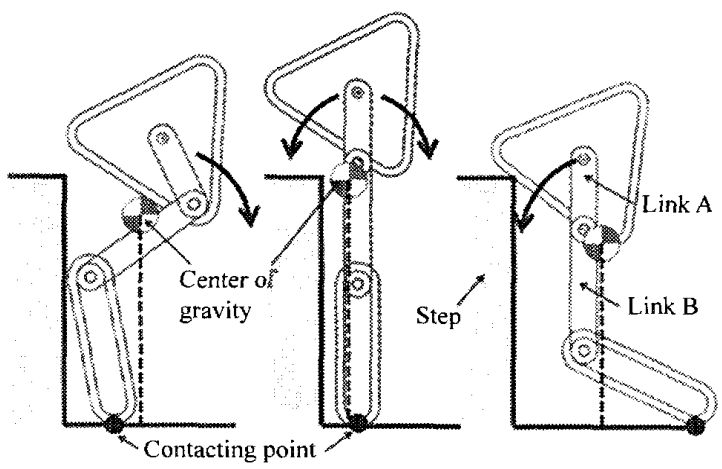

Fig. 11 Analysis of COG positions in different postures and shapes while climbing process.

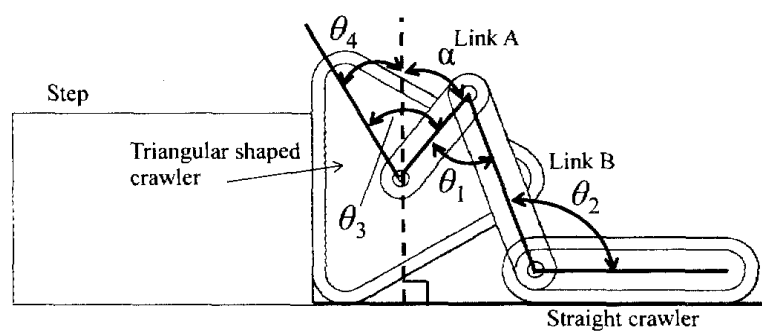

Fig. 12 Parameters for climbing motion algorithm.

各モータの角度情報だけである，それらより，ロボッ トの姿勢を計算する. 図 12 に示すように，リンクA． $\mathrm{B}$ 間の角度を $\theta_{1}$, リンク $\mathrm{B} ・$ 直線クローラ間の角度を $\theta_{2}$, 三角クローラのリンク $\mathrm{A}$ に対する回転角度を $\theta_{3}$, 三角クローラの鉛直軸に対する回転角度を $\theta_{4}$ とする. $\theta_{4}=\theta_{3}-\alpha$ の関係にある. 以下に，段差登りのアル ゴリズムを示す.

1：前提として段差側面に対して三角クローラ双方が 対面・接触（正対）した状態にする.

(図 4(a), $\theta_{1}=30^{\circ}, \theta_{2}=120^{\circ}$ )

2: 2 つの三角クローラを段差側面に沿うように一定 のトルク $T_{1}(=2.5 \mathrm{Nm})$ で中心軸周りに回転させる.

以降,トルクを保持.

3: 4 つのクローラを同じ一定の推力 $(20 \mathrm{~N})$ て駆動し, 前進移動とグリップ力を確保する. 以降, 推力を保 持.

4: 三角クローラが壁面まで回転したことを検知した ら (図 4(b), $\theta_{4}=30^{\circ}$ )， $\theta_{1}$ を現在の角度加 $180^{\circ}$ 


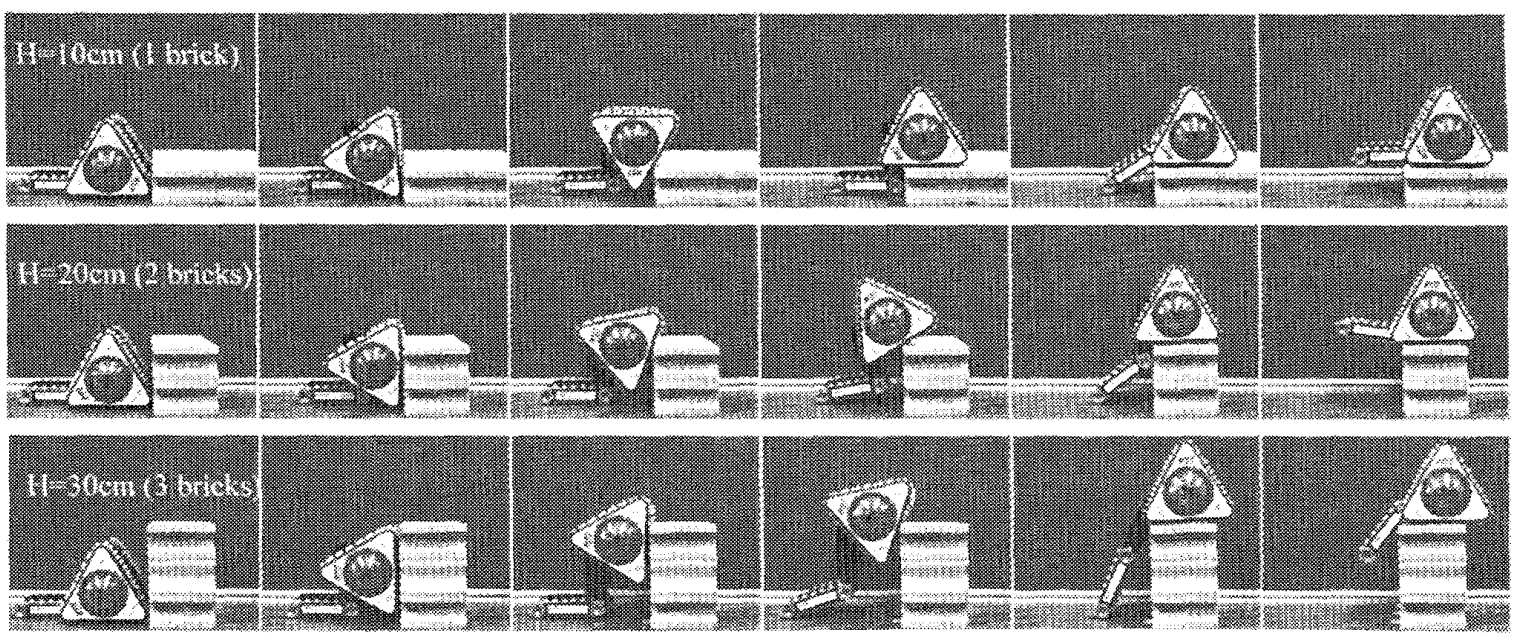

Fig. 13 Hardware experiments on different-height steps' climbing $(10 \mathrm{~cm}, 20 \mathrm{~cm}$ and $30 \mathrm{~cm})$ using proposed climbing motion algorithm.

（リンク A・B が直線状態）になるまで一定速度

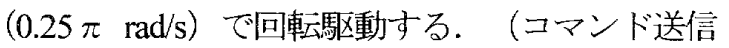
後モータが自動で実行)。

5: リンク $\mathrm{B}$ の鉛直からの角度 $\theta_{1}-\alpha$ の值が負の場合, リンクBが鉛直になるように，日帛制御する。

6: $\theta_{1}$ が $100^{\circ}$ を越えた時点で， $\theta_{2}$ を最大 $180^{\circ}$ にな るまで一定速度 $(0.25 \pi \mathrm{rad} / \mathrm{s})$ で回転駆動する（コ マンド送信後モータが自動で害行)。(図4(c))

7: 三角クローラが段差面に着地したことを検知した ら (図 4(d), $\left.\theta_{4}=120^{\circ}\right)$, 以下を実行し 8 にい。 そうでない場合は 5 に戻る。

$\theta_{1}$ を固定し， $\theta_{2}$ を最大 $180^{\circ}$ になるまで一定速 度 $(0.25 \pi \mathrm{rad} / \mathrm{s})$ で回転駆動する（コマンド送信 後モータが自動で実行）。三角クローラの中心軸周 りのトルクを解除（回転をフリーにする）。

8: リンク $\mathrm{B}$, 直線クローラの段差面への引き上げ動作 を実行する（図 $4(\mathrm{e}) \rightarrow(\mathrm{f})$ ) 。

\section{5. ハードウェア実倹}

$5 \cdot 1$ 自動段差登りアルゴリスムの検証 $4 \cdot 2$ の 自動段差越えアルゴリズムの検証実験を行った。図 13 に，段差（ブロック）の高さを $10 \mathrm{~cm}$ (1 個)， $20 \mathrm{~cm}(2$ 個）， $30 \mathrm{~cm}$ （3 個）とした場合の段差登りの様子を示 す.図13から, 高さが様々に変化した場合も, 三角ク ローラの回転を利用した段差検知により動作を変更す ることでスムーズな段差登りが実現できていることが 分かる. 本実験から，提案した段差登りアルゴリズム は，未知の高さの段差に対応可能であることを確認し た. 実験の様子は，ホームページ(13)をご覽頂きたい．

\section{2一般環境における段差越え実験 図 14 にお} ける実験では，一般環境にお污る段差を想定して，階 段，円筒形の障害物，屋外におう打不定形な切り株登
り，またチャレンジとして $36 \mathrm{~cm}$ の高段差について自 動段差登りアルゴリズムの検証を行った。階段登り実 験では，一段毎に自動段差登りアルゴリズムを起動す ることで，ちょうど1階分にあたる段数を全て走破し た．また，提案のアルゴリズムは，直角の段差に限ら ず，円筒形状のものでも登ることができることを確認 した，さらに，最大 $36 \mathrm{~cm}$ までの段差登りが可能であ ることを確認した.この高さは DIR-2 の約 1.5 倍の高 さにあたり，本機構を用いれば，より小型で階段を登 るロボットを実現できることを示している.

\section{6. 結詇と今後の課題}

本論文では，小型でありながら約 1.5 倍の高さの段 差まで走破可能なクローラロボット機構を提案した。

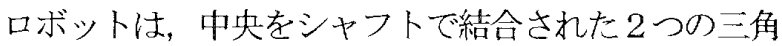
形状のクローラュニット, 直線状のクローラニニット, およびシャフトと直線クローラを結ぶ 2 リンク機構か ら構成され，全部で 8 自由度ある. 段差を登る際は， クローラによるグリップとリンク機構を駆動して，最 も重い三角クローラ部を先に段差に載せ，その他を後 から持ち上げることで行う。また，段差の高さによら ず, 自動的に段差に登るためのアルゴリズムを提案し， 実験によりロボット機構と提案手法の有效性を確認し た. 実験では，人工的な段差（2 次元問題）は登れる 事を確認しているが，災害後の瓦砅など予測できない 不定な几几がある場所（3 次元問題）では，未だロボ ットの移動制御に执いて難しい問題が残されている. また，本論文で提案した手法では，口ボットを高い段 差に載せることはできるが，高い段差から滑らかにお ろすことはできない. $20 \mathrm{~cm}$ 程度の高さであれば，その まま落ちても問題ないが，それ以上になると機構への 負担が大きく，今後，ロボット自身の頑健性の向上に 

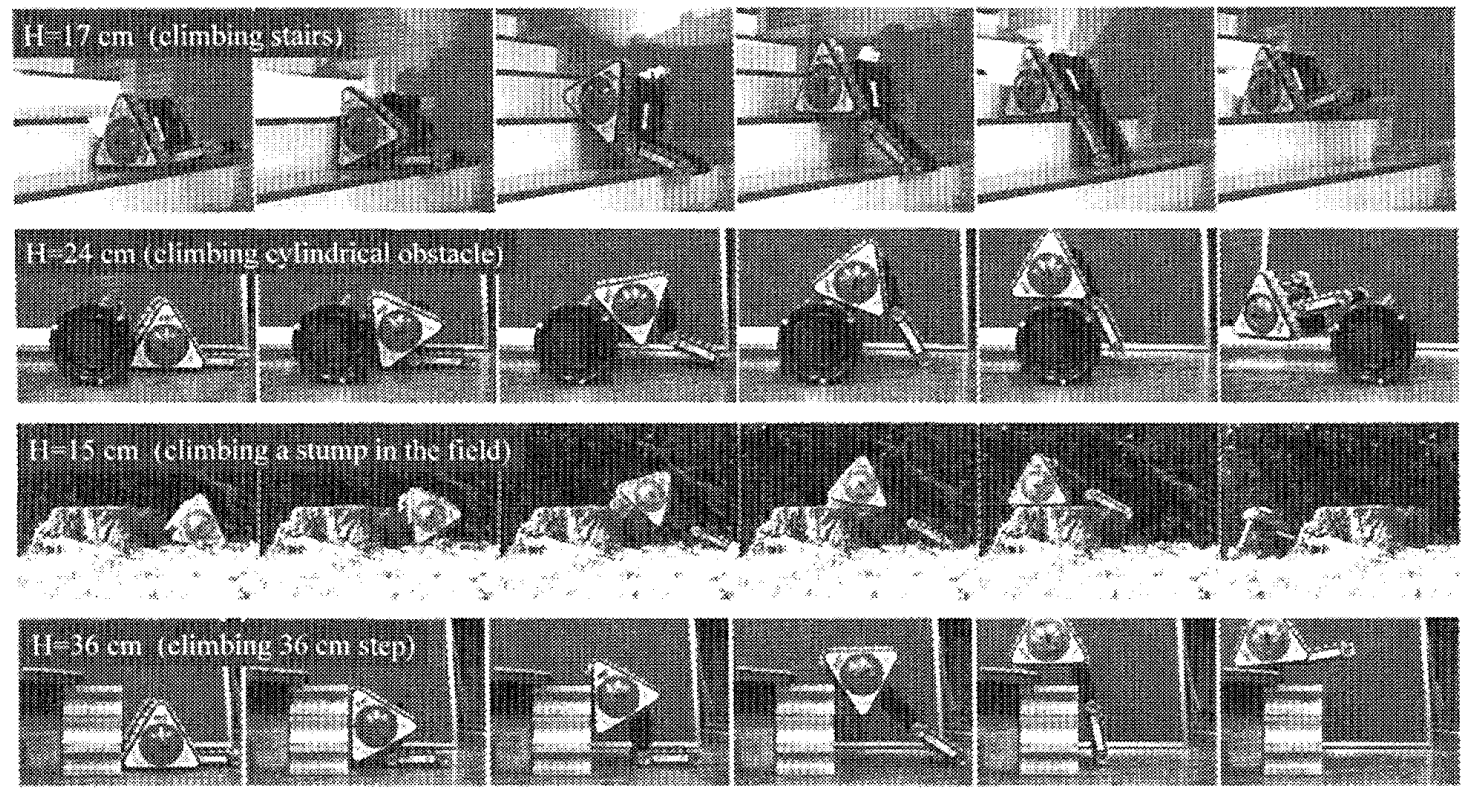

Fig. 14 Hardware experiments on climbing in various situations.

加え，自動段差降り手法の開発も課題の一つとして考 えている.

\section{梼辞}

本研究のロボット開発において，(株) AUC ${ }^{(12)}$ の蓮見啓二氏と村川卓也氏にはロボットの企画や 設計など多大なるサポートを頂いたここに謝意 を表する。また，4章の自動段差登り動作の実現 において，(独）産業技術総合研究所 知能シス テム研究部門の黒河治久氏に幾何学的な解析，口 ボットの制御手法に関してアドバイスを頂いた。 ここに謝意を表する。

\section{文献}

(1) Woosub Lee, Sungchul Kang, Munsang Kim, Mignon Park, ROBHAZ-DT3: teleoperated mobile platform with passively adaptive double-track for hazardous environment applications, Proceedings of IEEE/RSJ Int. Conf. on Intelligent Robots and Systems (IROS), (2004), pp. 33 - 38.

(2) Mesa Robotics, Inc. "Matilda robotic platform". Mesa Robotics homepage. (online), available from<http://www.mesa-robotics.com/matilda.html>, (accessed 2009-2-26).

(3) Katsuura, T., Ishida, H., Nagatani, K., Tanaka, Y., "Development of a Searching Mobile Robot loaded with a 3D Range Sensor observable from Many View Point in the Rubble", Proceedings of JSME Robotics and Mechatronics Conference 2004, 2P2-H-22 (2004-06).

(4) Brian Yamauchi, PackBot: A Versatile Platform for Military Robotics, Proceedings of SPIE on Unmanned Ground Vehicle Technology VI, vol. 5422, (2004), pp. 228-237.

(5) Kazunori Ohno, Shouich Morimura, Satoshi Tadokoro, Eiji Koyanagi and Tomoaki Yoshida, Semi-autonomous Control System of Rescue
Crawler Robot Having Flippers for Getting Over Unknown-Steps, Proceedings of IEEE/RSJ Int. Conf. on Intelligent Robots and Systems (IROS), (2007), pp. $3012-3018$

(6) Miyanaka, H., Wada, N., Kamegawa, T., Sato, N., Tsukui, S., Igarashi, H., Matsuno, F., Development of an unit type robot "KOHGA2" with stuck avoidance ability, Proceedings of IEEE/RSJ Int. Conf. on Robotics and Automation (ICRA), (2007), pp. $3877-3882$.

(7) Moosavian, S.A.A., Semsarilar, H., Kalantari, A., Design and Manufacturing of a Mobile Rescue Robot, Proceedings of IEEE/RSJ Int. Conf. on Intelligent Robots and Systems (IROS), (2006), pp. $3982-3987$.

(8) Masayuki, A., Takayama, T., Hirose, S., Development of "Souryu-III": connected crawler vehicle for inspection inside narrow and winding spaces, Proceedings of IEEE/RSJ Int. Conf. on Intelligent Robots and Systems (IROS), (2004), pp. $52-57$.

(9) Kamegawa, T., Yamasaki, T., Matsuno, F., Evaluation of snake-like rescue robot "KOHGA" for usability of remote control, Proceedings of IEEE International Workshop on Safety, Security and Rescue Robotics (SSRR), (2005), pp.25-30.

(10) Sato, N., Matsuno, F., Shiroma, N., FUMA: Platform Development and System Integration for Rescue Missions, Proceedings of IEEE International Workshop on Safety, Security and Rescue Robotics (SSRR), (2007), pp.1-6.

(11) Guarnieri, M., Debenest, R., Inoh, T., Fukushima, E., Hirose, S., Development of Helios VII: an arm-equipped tracked vehicle for search and rescue operations, Proceedings of IEEE/RSJ Int. Conf. on Intelligent Robots and Systems (IROS), (2004), pp. $39-45$.

(12) AUC Inc. (online), available from<http://adv.u-corp.jp/index.html $>, \quad$ (accessed 2009-2-26).

(13) Akiya Kamimura "DIR-2 performance movies". (online), available from $<$ http://staff.aist.go.jp/kamimura.a/dir2/movie.ht $\mathrm{m}>$, (accessed 2009-2-26). 